\title{
Partial coverage methylammonium lead bromide films for solar cell application
}

\author{
Asya Mhamdi ${ }^{\mathrm{a}, \mathrm{b}^{*}}$, Nuria Vicente $^{\mathrm{b}}$, Abdelaziz Bouazizi $^{\mathrm{a}}$, Germà Garcia-Belmonte $^{\mathrm{b}}$ \\ ${ }^{a}$ Équipe Dispositifs Électroniques Organiques et Photovoltä̈que Moléculaire, Laboratoire de la \\ Matière Condensée et des Nanosciences, Faculté des Sciences de Monastir,Université de \\ Monastir, Avenue de l'environnement, 5019 Monastir, Tunisia. \\ ${ }^{b}$ Institute of Advanced Materials (INAM), Universitat Jaume I, 12006 Castelló, Spain
}

\begin{abstract}
Hybrid perovskite compounds as methylammonium lead halides are currently been investigated for different optoelectronic applications. $\mathrm{CH}_{3} \mathrm{NH}_{3} \mathrm{PbBr}_{3}$ is a promising member because of its electronic structure and large bandgap that gives rise to a high open circuit voltage. Although higher performances can result by using sophisticated processing, one-step methods are particularly interesting because of their easy implementation. Solar cells based on $\mathrm{CH}_{3} \mathrm{NH}_{3} \mathrm{PbBr}_{3}$ are fabricated using one-step spin coating deposition. Remarkable effect on the morphological, structural, optical and electrical properties is observed by changing the molar ratio of the precursors. Dual film morphology, with micrometer-size $\mathrm{CH}_{3} \mathrm{NH}_{3} \mathrm{PbBr}_{3}$ crystals embedded in a mesoporous $\mathrm{TiO}_{2}$ background, explains minimal shunting paths and open-circuit voltage reduction. Full perovskite coverage of $\mathrm{TiO}_{2}$ background is not necessary for proper operation.
\end{abstract}

Keywords: perovskite; film deposition; optical properties; photovoltaics; methylammonium lead bromide.

*Corresponding author: Asya Mhamdi, (mhamdiasya@gmail.com) 


\section{Introduction}

The successful introduction of hybrid perovskite compounds as methylammonium lead halides, acting as light absorber materials [1, 2], have fostered an unprecedented development of the so called perovskite solar cells (PSCs) reaching photovoltaic efficiencies as high as $24.2 \%$ [3]. The use of these compounds has been extended into other optoelectronic [4-6], and even lasing [7, 8] applications. These devices basically consist of a layered architecture where the absorber perovskite is sandwiched between an electron transport material, regularly $\mathrm{TiO}_{2}$, and a hole transport material (HTM), usually made of the organic compound 2,2',7,7'-tetrakis(N,N-di-pmethoxyphenylamine)-9,9-spirobifluorene (spiro-OMeTAD) $[9,10]$. The most commonly used absorbing materials are $\mathrm{CH}_{3} \mathrm{NH}_{3} \mathrm{PbI}_{3}[11,12]$ and $\mathrm{CH}_{3} \mathrm{NH}_{3} \mathrm{PbI}_{3-x} \mathrm{Cl}_{x}$ $[13,14]$, although $\mathrm{CH}_{3} \mathrm{NH}_{3} \mathrm{PbBr}_{3}\left(\mathrm{MAPbBr}_{3}\right)$ has also received particular attention [15, 16] because of its wide bandgap. These materials are used in different types of cells. Firsly, they were implemented as sensitizers for titania electordes in a liquid junction solar cell giving efficiencies of $3.8 \%$ with $\mathrm{CH}_{3} \mathrm{NH}_{3} \mathrm{PbI}_{3}$ and $3.1 \%$ with $\mathrm{CH}_{3} \mathrm{NH}_{3} \mathrm{PbBr}_{3}$ [17]. Then, hybrid perovskites were used in all-solid-state solar cells to achieve higher efficiency. $\mathrm{CH}_{3} \mathrm{NH}_{3} \mathrm{PbBr}_{3}$ exhibits a higher open-circuit voltage $\left(\mathrm{V}_{\mathrm{OC}}\right.$ ) compared to $\mathrm{CH}_{3} \mathrm{NH}_{3} \mathrm{PbI}_{3}$ because of its wider bandgap. Voc values have risen from $0.96 \mathrm{~V}$ in 2009 to $1.3 \mathrm{~V}$ by Edri et al. in 2013 [18], up to $1.45 \mathrm{~V}$ in 2015 by Sheng et al. [19]. Also in these studies, an increase in the values of Jsc and FF has been noticed.

Furthermore, the fabrication techniques are known to influence the quality of the optoelectronic films. Four different deposition methods were reported in different works: one-step spin coating [20], two-step spin coating [21], dual source vapor assisted [22] and vapor assisted solution process [23]. For $\mathrm{MAPbBr}_{3}$ based solar cells, the highest efficiency of $10.4 \%$ has been reported by Heo et al. [24] using crystallization controlled spin-coating process. The values of short-circuit current density $\left(\mathrm{J}_{\mathrm{sc})}\right.$ and fillfactor (FF) for their study were $8.4 \mathrm{~mA} / \mathrm{cm}^{2}$ and $82 \%$, respectively. Although higher performances can result by using sophisticated processing, one-step methods are particularly interesting because they can be easily implemented $[15,16]$. For instance, Cai et al. realized $\mathrm{MAPbBr}_{3}$-based solar cells using the one-step spin coating method and the Poly[N-90-heptadecanyl-2,7carbazole-alt-3,6-bis(thiophen-5-yl)-2,5-dioctyl2,5-dihydropyrrolo[3,4]pyrrole-1,4-dione] (PCBTDPP) polymer as HTM [25]. This 
photovoltaic device based on $\mathrm{MAPbBr}_{3}$ displays a high $\mathrm{V}_{\mathrm{OC}} \sim 1.16 \mathrm{~V}, \mathrm{FF} \sim 0.59$ and $\mathrm{Jsc} \sim 4.47 \mathrm{~mA} / \mathrm{cm}^{2}$. More efforts should be done to deeply explore the suitability of onestep deposition methods for optoelectronic and photovoltaic applications.

In this paper, solar cells based on $\mathrm{MAPbBr}_{3}$ with the structure $\mathrm{FTO} / \mathrm{TiO}_{2} / \mathrm{MAPbBr}_{3} / \mathrm{Spiro-OMeTAD} / \mathrm{Au}$ was fabricated. The $\mathrm{MAPbBr}_{3}$ layer was deposited by one-step spin coating of the precursor solution and the effect of the variation of the $\mathrm{MaBr}$ molar ratio in the solution was investigated. Remarkable effect on the morphological, structural, optical and electrical properties was demonstrated. The Jsc and FF obtained in this report are in good agreement with those obtained previosuly for one-step methods [25]. Dual film morphology, with $\mathrm{MAPbBr}_{3}$ micrometer-size crystals embedded in a small mesoporous $\mathrm{TiO}_{2}$ background, explains the achieved low Voc values because of the detrimental charge recombination occurring at grain boundaries. It is noticed that full perovskite coverage of $\mathrm{TiO}_{2}$ background is not necessary for proper operation.

\section{Experimental Section.}

\subsection{Synthesis and device fabrication.}

The substrate used was an F-doped $\mathrm{SnO}_{2}$ (FTO) conducting glass $\left(25^{*} 25 \mathrm{~mm}, 15 \Omega / \mathrm{sq}\right.$ resistance). These substrates were patterned with $\mathrm{HCl}$ and zinc powder, then they were cleaned in Hallmanex detergent and rinsed with deionized water and ethanol, acetone and isopropanol. A blocking layer of $\mathrm{TiO}_{2}$ was deposited onto the FTO glass by spray pyrolysis at $450{ }^{\circ} \mathrm{C}$ for $35 \mathrm{~min}$, using a solution of titanium diisopropoxide bis(acetylacetonate) (75\% in isopropanol, Sigma Aldrich) in ethanol. The mesoporous $\mathrm{TiO}_{2}$ layer ws deposited on top of the blocking layer by spin coating (2000 rpm) with an acceleration of $2000 \mathrm{rpm}$, during $10 \mathrm{~s}$ ) using $100 \mu \mathrm{L}$ of a solution of a $\mathrm{TiO}_{2}$ paste (Dyesol 30-NRD, $30 \mathrm{~nm}$ average particle size) diluted in ethanol absolute. The obtained films were then dried at $100{ }^{\circ} \mathrm{C}$ for $10 \mathrm{~min}$ and annealed at $500{ }^{\circ} \mathrm{C}$ for $30 \mathrm{~min}$. The $\mathrm{MAPbBr}_{3}$ solution was prepared by reacting $\mathrm{N}$,Ndimethylformamide solutions (50 wt $\%$ ) containing $\mathrm{PbBr}_{2}, \mathrm{MABr}$, and Dimethylsulfoxide (DMSO) with various molar ratio of $\operatorname{MABr}(1: 0.5: 1,1: 075: 1,1: 1: 1,1: 1.25: 1,1: 1.5: 1)$ respectively. The solution was deposited using one step spin-coating at $4000 \mathrm{rpm}$ for $50 \mathrm{~s}$. After deposition, the 
substrate was heated up at $65{ }^{\circ} \mathrm{C}$ for $1 \mathrm{~min}$, sufficient temperature to remove entirely DMSO, and then annealing at $100{ }^{\circ} \mathrm{C}$ for $2 \mathrm{~min}$. To complete the solar devices, the perovskite film was covered with the hole-transporting material (HTM) by dynamically spin coating at $4000 \mathrm{rpm}$ for $30 \mathrm{~s}$, using $50 \mu \mathrm{l}$ of spiro-OMeTAD. The spiro-OMeTAD solution was prepared by dissolving; $72.3 \mathrm{mg}$ of (2,2',7,7'-tetrakis(N-N'-di-pmethoxyphenylamine)-9-9'-spirobifluorene), 28,8 $\mu$ l of 4-tert-butylpyridine, and $17.5 \mu 1$ of a stock solution of $520 \mathrm{mg} / \mathrm{ml}$ of lithium bis-(trifluoromethylsulfonyl)imide in acetnotrile in $1 \mathrm{ml}$ of chlorobenzene. The samples were left overnight in dry air before $100 \mathrm{~nm}$ gold contacts were thermally evaporated on top of the device to form the electrode contact (Fig. 1).

\subsection{Characterization methods.}

The structural properties MAPbBr3 was studied using X-ray diffraction (XRD) using Bruker AXS-D4Endeaver Advance X-ray diffractometer using $\mathrm{Cu} \mathrm{k \alpha}$, wavelength $\lambda=1.5406 \AA$, working with the Bragg-Brentano geometry. The surface morphologies of MAPbBr3 films were analyzed by scanning electron microscope using a JEOL JEM$3100 \mathrm{~F}$ field emission scanning electron microscope (FEG-SEM) with $15 \mathrm{kV}$ acceleration voltage. The optical properties of the perovskite films were obtained by UV-vis spectroscopy using a Varian Cary 300 Bio spectrophotometer and the photoluminescence PL spectra were obtained by using an fluorimeter Horiba FL-1000 with an excitation wavelength of $430 \mathrm{~nm}$. The current density-voltage $(\mathrm{J}-\mathrm{V})$ curves were recorded under AM $1.5 \mathrm{G}\left(100 \mathrm{~mW} . \mathrm{cm}^{-2}\right)$ by a solar simulator (ABET Technologies Sun 2000) with a Keithley 2400.

\section{Results and discussion.}

\subsection{Structural properties.}

Controlling the ratio of the composite is also a crucial factor to achieve high performance. Given in Fig. (2) are the XRD patterns of $\mathrm{MAPbBr}_{3}$ prepared with different molar ratio of $\mathrm{MABr}$ as mentioned in the experimental section and deposited on $\mathrm{FTO} / \mathrm{TiO}_{2}$ substrates. This figure shows a set of sharp reflections peaks at the following $2 \theta$ values: $14.9^{\circ}, 21.5^{\circ}, 25.6^{\circ}, 26.7^{\circ}, 30.1^{\circ}, 33.9^{\circ}, 37.9^{\circ}, 43.4^{\circ}$ and $46^{\circ}$. We defined $\mathrm{M}$ as the proportional coefficient of the molar ratio of $\mathrm{MABr}$ in $\mathrm{PbBr}_{2}: \mathrm{MABr}$ : DMSO. For all samples, strong peak are located at $14.9^{\circ}$ and $30.1^{\circ}$, corresponding to the (1 $\left.\begin{array}{lll}1 & 0\end{array}\right)$ and (2 000 ) planes, which confirms the formation of a cubic perovskite structure 
with a high crystallinity. The intensity of these diffraction peak increase when $M$ increases from 0.5 to 0.75 , then it decrease when $M=1$ and it increases again with increasing $\mathrm{M}$ to 1.25 and 1.5. The XRD patterns show clearly that the change of molar ratio of $\mathrm{MABr}$ effect on the crystallinity of the $\mathrm{MAPbBr}_{3}$ films. The concentration of the precursor has remarkable effect on the morphology of organic-inorganic halide perovskites, which influences the photovoltaic performance [26-27].

\subsection{Morphological properties.}

The variation in the XRD result can be an indicative of a change in the morphology of MAPbBr 3 deposited on mesoporous $\mathrm{TiO}_{2}$ layer. Therefore, we have examined the perovskite with different ratio of $\mathrm{MABr}$ sing scanning electron microscope (SEM). Figure (3) shows SEM images of $\mathrm{MAPbBr}_{3}$ films deposited on $\mathrm{m}-\mathrm{TiO}_{2} / \mathrm{FTO}$ with different ratio of $\mathrm{MABr}$. A, B, C, D and $\mathrm{E}$ images has similar morphology: low magnification SEM micrograph shows highly dense and uniform crystals. However, with higher magnification, the SEM image for all ratio of MABr shows an isolated large crystals which are micrometer-sized cubes in agreement with their cubic symmetry [28]. These large crystals are embedded in a backgorund formed by much small crystals. The increase of $\mathrm{MABr}$ content in the precursor of solution promotes the growth of large $\mathrm{MAPbBr}_{3}$ crystals. The number of large crystallites increase when $M$ increase from 0.5 to 0.75 , then it decrease when $M=1$, with the increase of the size of large crystals, and it increases again for $M=1.25$ and $M=1.5$. These results are similar with that of $\mathrm{MAPbI}_{3}$ [29] and $\mathrm{MAPbBr}_{3}$ [30]. The SEM images reveal the formation of a dual morphology including large $\mathrm{MAPbBr}_{3}$ micrometer-sized crystals on a nano-sized background. The background comprises the $\mathrm{TiO}_{2}$ mesoporous layer. Although this structure does not assure the whole perovskite coverage, it is beneficial for the performance of devices as the mesoporous $\mathrm{TiO}_{2}$ avoids electrical shorts.

\subsection{Optoelectronic properties.}

The change of the molar ratio of MABr has also an effect on the optical properties of the $\mathrm{MAPbBr}_{3}$ films. To study the variation of optical properties of $\mathrm{MAPbBr}_{3}$ films, UVVis absorption and photoluminescence measurement were studied. The absorbances of $\mathrm{MAPbBr}_{3}$ films deposited on top of $\mathrm{m}-\mathrm{TiO}_{2} / \mathrm{FTO}$ were measured by an UV-vis spectroscopy using Varian cary 300 Bio spectroscopy. The Ultraviolet- visible (UV-vis) absorption spectra of the perovskite material deposited on mesoporous $\mathrm{TiO}_{2}$ with 
different ratio of $\mathrm{MABr}$ are presented in Fig. 4. The samples shows the typical absorption spectrum of the perovskite $\mathrm{CH}_{3} \mathrm{NH}_{3} \mathrm{PbBr}_{3}$ as previously reported [31- 32]. Increasing the molar ratio of $\mathrm{MABr}$ from $M=0.5$ to $M=1.25$ shows a slight increase in the absorbance then it decrease with $M=1.5$.

The variation of the absorbance intensity is usually consistent with that of the emission wavelength. Therefore, the photoluminescence (PL) emission spectra of $\mathrm{CH}_{3} \mathrm{NH}_{3} \mathrm{PbBr}_{3}$ with different ratio of $\mathrm{MABr}$ were measured with excitation wavelength at $430 \mathrm{~nm}$. Figure. 5 shows the PL emission spectra of $\mathrm{MAPbBr} 3$ with different ratio of $\mathrm{MABr}$ between $450 \mathrm{~nm}$ and $650 \mathrm{~nm}$. This figure displays the relationship between the molar ratio of $\mathrm{MABr}$ and the $\mathrm{PL}$ intensity of $\mathrm{MAPbBr} 3$. The photoluminescence peak position for all the substrates of $\mathrm{MAPbBr}_{3}$ were centred at $540 \mathrm{~nm}$ as previously reported [3319]. While, the emission intensity change with changing the molar ratio of the $\mathrm{MABr}$ in the solution precursor. The $\mathrm{MAPbBr}_{3}$ films fabricating from $\left(\mathrm{PbBr}_{2}: \mathrm{MABr}: \mathrm{DMSO}=1: 0.75: 1\right)$ exhibit the strongest PL emission intensity. Then, the intensity decrease with the increase of the ratio of $\operatorname{MABr}(M=1)$ which is consistent with the reduction of grain in SEM images. The reduction of the number of large crystals induce the decrease of the photoluminescence intensity [30]. Further increasing the $\mathrm{MABr}$ concentration produces the decreases of $\mathrm{PL}$ intensity of $\mathrm{MAPbBr}_{3}$ for $\mathrm{M}=$ 1.25 and 1.5. As shown in SEM studies of $\mathrm{MAPbBr}_{3}$ thin films (Fig. 3), when the number of large crystals decrease, the size of crystals increase and the spacing between individual crystals becomes bigger. For $M>1$ the surface shows smaller spacing between crystals. The decrease of spacing between crystals leads to the decrease of PL intensity [30].

\subsection{Photovoltaic performance.}

Additionally to the materials properties, the composition employed for the preparation of hybrid perovskites can improve the performance of the solar cells. To further understand, current-voltage measurements (Fig. 6) were carried out on $\mathrm{CH}_{3} \mathrm{NH}_{3} \mathrm{PbBr}_{3}$ based devices with different concentration of MABr under standard air mass 1.5 global (AM 1.5 G) illumination. Table 1 summarizes the photovoltaic parameters Jsc, Voc and fill factor $(\mathrm{FF})$. 
Interestingly, devices containing the perovskite with the composition $(1: 1: 1)$ in $\left(\mathrm{PbBr}_{2}\right.$ : MABr: DMSO) revealed the best photovoltaic performance. This device exhibits a short circuit current density (Jsc) of $5.16 \mathrm{~mA} / \mathrm{cm}^{2}$, an open circuit voltage (Voc) of $0.888 \mathrm{~V}$ and fill factor (FF) of 73.5, resulting in an overall power conversion efficiency $(\eta)$ of $3.36 \%$ (Figure 6). The increase of the values of Voc, FF and $\eta$ has been shown to be an indicator of film quality. Also these values for $M=1$ indicate minimal shunting paths between $\mathrm{TiO}_{2}$ and spiro-OMeTAD. As can be seen, the efficiency of the device is found to decline slightly for $\mathrm{M}=0.5$ (with efficiency $\eta=3.1 \%$ ) and for $\mathrm{M}=0.75$, the efficiency was decreased to $1.8 \%$. Also, when the concentration of $\mathrm{MABr}$ increase for $\mathrm{M}=1.25$ and $\mathrm{M}=1.5$, the efficiency of $\mathrm{MABr}$ decrease respectively to $1.4 \%$ and $2.02 \%$. Remarkably, the higher efficiency, Jsc, and FF are obtained for $\mathrm{M}=1$. The film morphology for that $\mathrm{MABr}$ molar ratio is observed to include the largest crystals. There is therefore a direct relationship between the perovskite crystal size and the device performance. It is also notice that the achieved ( Voc $\sim 0.9 \mathrm{~V}$ ) is below the expected values corresponding to this wide bandgap semiconductor $(\mathrm{Eg} \sim 2.3 \mathrm{eV})$. The small size of the backgound crystals are responsible for a high amount of grain boundaries in which defects concentrate. High defect density fosters charge recombination reducing, as a consequence, the achivable open-circuit voltage.

\section{Conclusion}

In conclusion, we report on one-step spin coating method for fabricating methylammonuim lead bromide perovskite film for optoelectronic application. Our result show that the change of molar ratio of $\mathrm{MABr}$ in the precursor solution has significant effect on the morphological, optical and electrical properties of $\mathrm{MAPbBr}_{3}$ based devices. The films present large cubic crystals in agreement with their cubic symmetry. The XRD and SEM data show dual crystallinity of the layers with large $\mathrm{MAPbBr} 3$ crystals ontop of mesoporous $\mathrm{TiO}_{2}$ backgraound minimizing shunting paths, and open-circuit voltage reduction. It is remarked that full perovskite coverage of $\mathrm{TiO}_{2}$ background is not necessary for proper operation. The best $\mathrm{MAPbBr}_{3}$ perovskite solar cell achieved a conversion efficiency of $3.46 \%$, Voc of $0.888 \mathrm{~V}, \mathrm{~J}_{\mathrm{SC}}$ of $5.16 \mathrm{~mA} / \mathrm{cm}^{2}$ and fill factor of 73.5 . 


\section{References}

[1] H.-S. Kim, C.-R. Lee, J.-H. Im, K.-B. Lee, T. Moehl, A. Marchioro, S.-J. Moon, R. Humphry-Baker, J.-H. Yum, J.E. Moser, M. Grätzel, N.-G. Park, Lead Iodide Perovskite Sensitized All-Solid-State Submicron Thin Film Mesoscopic Solar Cell with Efficiency Exceeding 9\%, Scientific Reports 2 (2012) 591.

[2] M.M. Lee, J. Teuscher, T. Miyasaka, T.N. Murakami, H.J. Snaith, Efficient Hybrid Solar Cells Based on Meso-Superstructured Organometal Halide Perovskites, Science 338 (2012) 643-647.

[3] National Renewable Energy Laboratory. Best research-cell efficiency chart. https://www.nrel.gov/pv/assets/images/efficiency-chart.png (2019).

[4] M. Jianli,. F. Zhang, Recent progress on highly sensitive perovskite photodetectors, Journal of Materials Chemistry C, 7 (2019) 1741-1791.

[5] V.Nuria, G. Garcia-Belmonte, Methylammonium lead bromide perovskite battery anodes reversibly host high li-ion concentrations, The journal of physical chemistry letters, 7 (2017) 1371-1374.

[6] I. Suárez, E.J. Juárez-Pérez, J. Bisquert , I. Mora-Seró, J.P. Martínez-Pastor, Polymer/Perovskite Amplifying Waveguides for Active Hybrid Silicon Photonics, Adv. Mater. 27 (2015) 6157-6162.

[7] F. Deschler, M. Price, S. Pathak, L.E. Klintberg, D.-D. Jarausch, R. Higler, S. Hüttner, T. Leijtens, S.D. Stranks, H.J. Snaith, M. Atatüre, R.T. Phillips, R.H. Friend, High Photoluminescence Efficiency and Optically Pumped Lasing in Solution-Processed Mixed Halide Perovskite Semiconductors, J. Phys. Chem. Lett. 5 (2014) 1421-1426.

[8] A. P. Schlaus, M.l S. Spencer, K. Miyata, F. Liu, X. Wang, I. Datta, M. Lipson, A. Pan, X.$\mathrm{Y}$. Zhu, How lasing happens in $\mathrm{Cs} \mathrm{PbBr} 3$ perovskite nanowires, Nature communications, 1 (2019) 265.

[9] J. Peia, K. Fenga, X. Zhaoa, Y. Haoa,Y. Weia, S. Chena, B. Suna,Y.Lia, H. Lvb. "ZnObased inverted hybrid solar cells using P3HT and spiro-OMeTAD with hole transporting property: Layered or blended." Chemical Physics Letters 729 (2019) 79-83.

[10] F. Zhang, S. Wang, X. Li, Y. Xiao, Recent Progress of Perovskite Solar Cells, Current Nanoscience 12 (2016) 137-156.

[11] C. C. Chen, S. H. Chang, L.C. Chen, C. L. Tsai, H. M. Cheng, W. C. Huang, W. N. Chen, Y. C. Lu, Z. L. Tseng, K. Y. Chiu, S. H. Chen, C. G. Wu, Interplay between nucleation and crystal growth during the formation of $\mathrm{CH}_{3} \mathrm{NH}_{3} \mathrm{PbI}_{3}$ thin films and their application in solar cells, Solar Energy Materials and Solar Cells 159 (2017) 583- 589.

[12] L. Jiang, J. Lu, S. R. Raga, J.Sun, X. Lin, W. Huang, F. Huang, U. Bach, Y. B. ChengJiang. "Fatigue stability of $\mathrm{CH} 3 \mathrm{NH} 3 \mathrm{PbI} 3$ based perovskite solar cells in day/night cycling." Nano Energy 58 (2019) 687-694.

[13] J. Liu, J. Lin, Q. Xue, Q. Ye, X. He, L. Ouyang, D. Zhuang, C. Liao, H. L. Yip, J. Mei , W. M. Lau Growth and evolution of solution-processed $\mathrm{CH}_{3} \mathrm{NH}_{3} \mathrm{PbI}_{3-\mathrm{x}} \mathrm{Cl}_{\mathrm{x}}$ layer for highly efficient planar-heterojunction perovskite solar cells, Journal of Power Sources 301 (2016) 242250 .

[14] P. Zhao, Z. Liu, Z. Lin, D. Chen, J. Su, Ch. Zhang, J. Zhang, J. Chang, Y. Hao "Device simulation of inverted $\mathrm{CH} 3 \mathrm{NH} 3 \mathrm{PbI} 3-\mathrm{xClx}$ perovskite solar cells based on PCBM electron transport layer and NiO hole transport layer." Solar Energy 169 (2018): 11-18.

[15] Y. H. Song, J. S. Yoo, E. K. Ji, C. W. Lee, G. S. Han, H. S. Jung, D.H. Yoon, Design of water stable green-emitting $\mathrm{CH}_{3} \mathrm{NH}_{3} \mathrm{PbBr}_{3}$ perovskite luminescence materials with 
encapsulation for applications in optoelectronic device, Chemical Engineering Journal 306 (2016) 791- 795.

[16] A. Mhamdi, H. Mehdi, A. Bouazizi, G. Garcia-Belmonte, One-step methylammonium lead bromide films: Effect of annealing treatment, Journal of Molecular Structure, 1192 (2019) 1-6.

[17] A. Kojima, K. Teshima, Y. Shirai,T. Miyasaka, Organometal Halide Perovskites as Visible-Light Sensitizers for Photovoltaic Cells, J. Am. Chem. Soc. 131 (2009) 6050-6051.

[18] E. Edri, S. Kirmayar, D. Cahan, G. Hodes, High Open-Circuit Voltage Solar Cells Based on Organic-InorganicLead Bromide Perovskite, J.Phys Chem. Lett 4 (2013) 897-902.

[19] R. Sheng, A. H. Baillie, S. Huang, S. Chen, X. Wen, X. Hao, M. A. Green, Methylammonium Lead Bromide Perovskite-Based Solar Cells by Vapour-Assisted Deposition Journal of Physical Chemistry C 119 (2015) 3545-3549.

[20] K. Wojciechowski, M. Saliba, T. Leijtens, A. Abate, H. J. Snaith, Sub- $150{ }^{\circ} \mathrm{C}$ processed meso-superstructured perovskite solar cells with enhanced efficiency, Energy Environ. Sci. 7 (2014) 1142.

[21] J. Burschka, N. Pellet, S. J. Moon, R. Humphry-Baker, P. Gao, M. K. Nazeeruddin, M. Gratzel, Sequential deposition as a route to high-performance perovskite-sensitized solar cells, Nature 499 (2013) 316- 319.

[22] M. Liu, M. B. Johnston, H. J. Snaith, Efficient planar heterojunction perovskite solar cells by vapour deposition, Nature 501 (2013)395- 398.

[23] Q. Chen, H. Zhou, Z. Hong, S. Luo, H. S. Duan, H. H. Wang, Y. Liu, G. Li, Y. Yang, Planar heterojunction perovskite solar cells via vapor-assisted solution process, J. Am. Chem. Soc. 136 (2014) 622- 625.

[24] J. H. Heo, D. H. Song, S. H. Im, Planar $\mathrm{CH}_{3} \mathrm{NH}_{3} \mathrm{PbBr}_{3}$ Hybrid Solar Cells with $10.4 \%$ Power Conversion Efficiency, Fabricated by Controlled Crystallization in the Spin-Coating Process, Adv. Mater. 26 (2014) 8179-8183.

[25] B. Cai, Y. Xing, Z. Yang, W.H. Zhang, J. Qiu, High performance hybrid solar cells sensitized by organolead halide perovskites, Energy Environ Sci. 6 (2013) 1480.

[26] M. I. Dar, N. Arora, P. Gao, S. Ahmad, M. Grätzel, M. K. Nazeeruddin, Investigation regarding the role of chloride in organic-inorganic halide perovskites obtained from chloride containing precursors , Nano Lett. 14 (2014) 6991-6996.

[27] Y. Ma, L. Zheng, Y. H. Chung, S. Chu, L. Xiao, Z. Chen, S. Wang, B. Qu, Q. Gong, Z. $\mathrm{Wu}, \mathrm{X}$. Hou, A highly efficient mesoscopic solar cell based on $\mathrm{CH}_{3} \mathrm{NH}_{3} \mathrm{PbI}(3-\mathrm{x}) \mathrm{Cl}(\mathrm{x})$ fabricated via sequential solution deposition, Chem. Commun. 50 (2014)12458-12461.

[28] Y.Tidhar, E. Edri, H. Weissman, D. Zohar, G. Hodes, D. Cahan, B. Rybtchinski, S. Kirmayar, Crystallization of Methyl Ammonium Lead Halide Perovskites:Implications for Photovoltaic Applications, J. Am. Chem. Soc. 136 (2014) 13249-13259.

[29] J. H. lm, I. H. Jang, N. Pellet, M. Grätzel, N. G. Park, Growth of $\mathrm{CH}_{3} \mathrm{NH}_{3} \mathrm{PbI}_{3}$ cuboids with controlled size for high-efficiency perovskite solar cells, Nature Nanotechnologie 9 (2014) 927932.

[30] J.Yan, X. Ke, Y. Chen, A. Zhang, B. Zhang, Effect of modulating the molar ratio of organic to inorganic content on morphology, optical absorption and photoluminescence of perovskite $\mathrm{CH}_{3} \mathrm{NH}_{3} \mathrm{PbBr}_{3}$ films, Applied Surface Science 351 (2015) 1191-1196. 
[31] Makhsud. I. S, Ahmed. L. A, Banavoth. M, Erkki. A, Victor. M. B, Wei. P, Ibrahim. D, Lingfei. W, Yao. H, Giacomo. M, Alain. G, Tom. W, Omar. F. M, Osman. M. B, High-quality bulk hybrid perovskite single crystals within minutes by inverse temperature crystallization, Nature Communications 6 (2015) 7586.

[32] Dong. S, Valerio. A, Riccardo. C, Mingjian. Y, Erkki. A, Andrei. B, Yin. C, Sjoerd. H, Alexander. R, Khabiboulakh. K, Yaroslav. L, Xin. Z, Peter. A. D, Omar. F. M, Edward. H. S, Osman. M. B, Low trap-state density and long carrier diffusion in organolead trihalide perovskite single crystals, Science 347 (2015) 519- 522.

[33] E. Edri, S. Kirmayer, M. Kulbak, G. Hodes, D. Cahen, Chloride Inclusion and Hole Transport Material Doping Improve Methyl Ammonium Lead Bromide Perovskite-based High Open-Circuit Voltage Solar Cells, J. Phys. Chem. Lett. 5 (2014) 429-433.

\section{Figure captions:}

Fig. 1: Structure of methylammonuim lead bromide perovskite solar cell.

Fig. 2: $\mathrm{XRD}$ patterns of $\mathrm{CH}_{3} \mathrm{NH}_{3} \mathrm{PbBr}_{3}$ films obtained with different ratio of $\mathrm{MABr}$

Fig. 3: $\mathrm{SEM}$ images of $\mathrm{MAPbBr}_{3}$ films with low and high magnification micrographs for different ratio of $\mathrm{MABr}$; $\mathrm{A}(\mathrm{M}=0.5), \mathrm{B}(\mathrm{M}=0.75), \mathrm{C}(\mathrm{M}=1), \mathrm{D}(\mathrm{M}=1.25), \mathrm{E}(\mathrm{M}=1.5)$.

Fig. 4: UV-vis absorption spectra of $\mathrm{MAPbBr}_{3}$ with different ratio of $\mathrm{MABr}$.

Fig. 5: Photoluminescence spectra of $\mathrm{MAPbBr}_{3}$ with different ratio of $\mathrm{MABr}$.

Fig. 6: Photovoltaic performance of perovskite devices: Current voltage characteristics of devices with different ratio of MABr.

\section{Table captions:}

Table 1: Photovoltaic performance of perovskite solar cells with different ratio of $\mathrm{MABr}$. 


\begin{tabular}{|c|c|c|c|c|}
\hline PbBr $_{2}:$ MABr:DMSO) & Voc (V) & Jsc (mA/cm & FF & Efficiency (\%) \\
\hline$(1: 0.5: 1)$ & 0.861 & 4.58 & 71.04 & 3.10 \\
\hline$(1: 0.75: 1)$ & 0.862 & 3.06 & 68.44 & 1.80 \\
\hline$(1: 1: 1)$ & 0.888 & 5.16 & 73.50 & 3.36 \\
\hline$(1: 1.25: 1)$ & 0.856 & 2.67 & 61.47 & 1.40 \\
\hline$(1: 1.5: 1)$ & 0.935 & 3.63 & 56.75 & 2.02 \\
\hline
\end{tabular}

Table 1 
Figure 1

Click here to download Figures (if any): Figure 1.docx

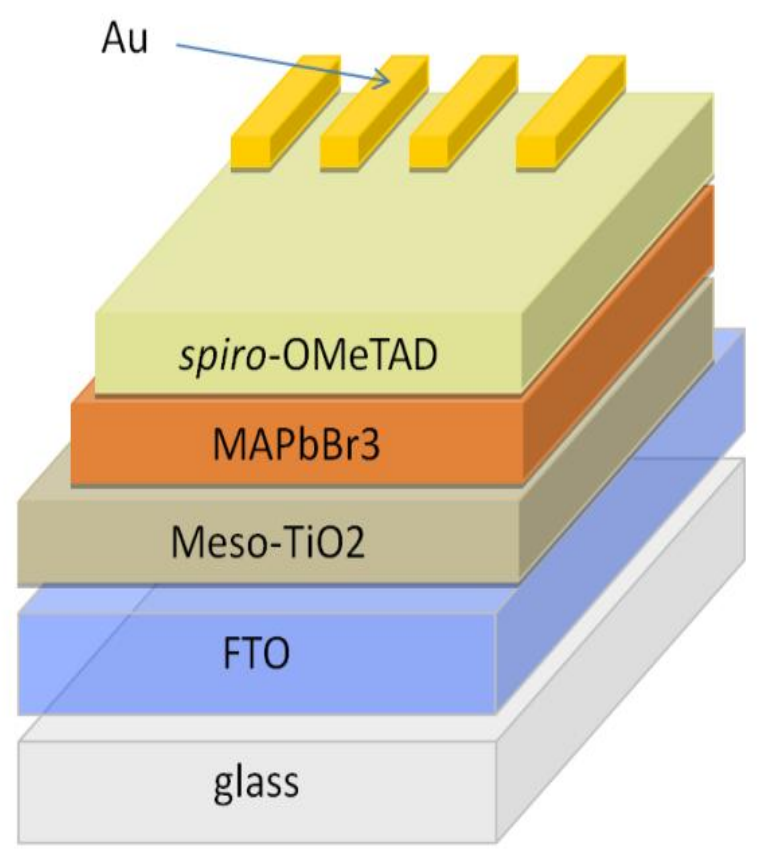

Fig.1 


\section{Figure 2}

Click here to download Figures (if any): Figure 2.docx

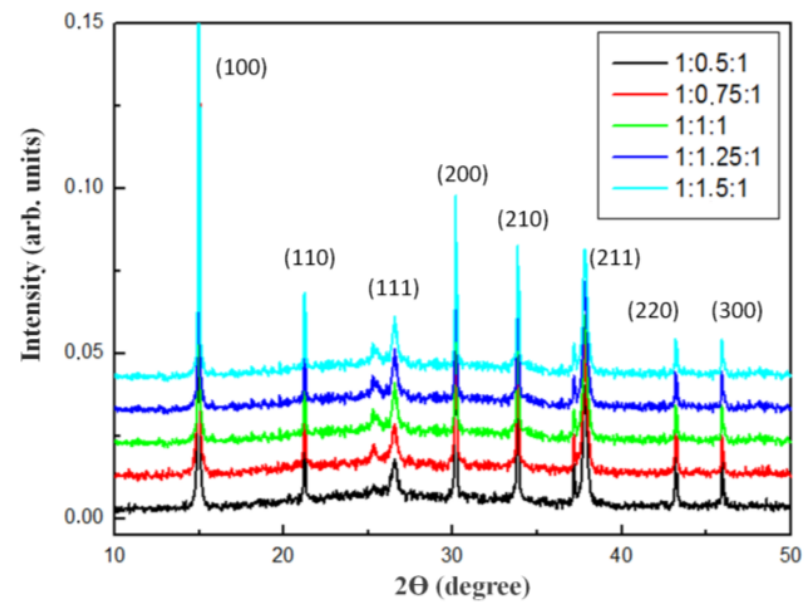

Fig.2 


\section{Figure 3}

Click here to download Figures (if any): Figure 3, no distortion, with readable marks.pptx
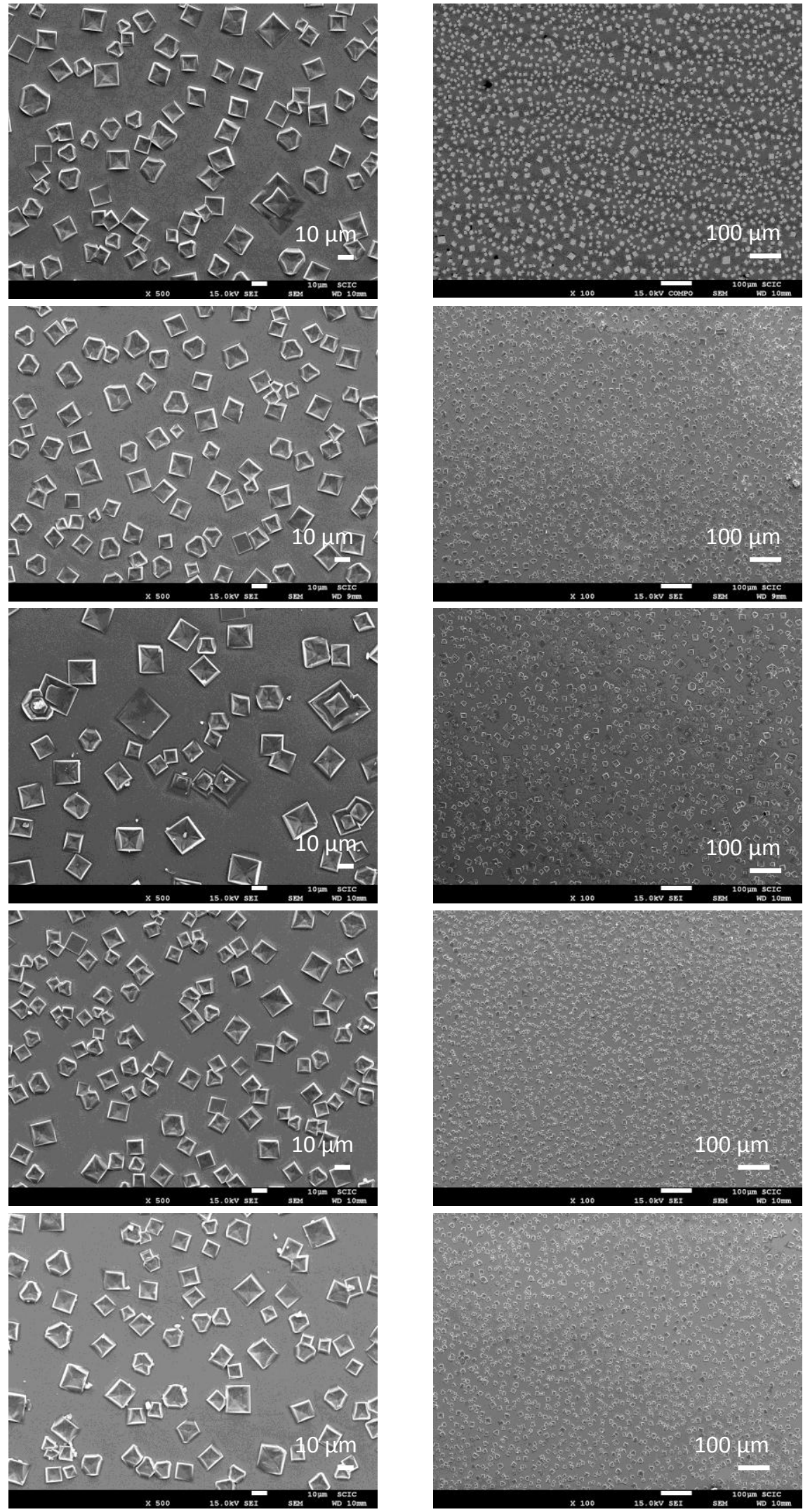
Figures 4 to 6

Click here to download Figures (if any): Figures 4 to 6. docx

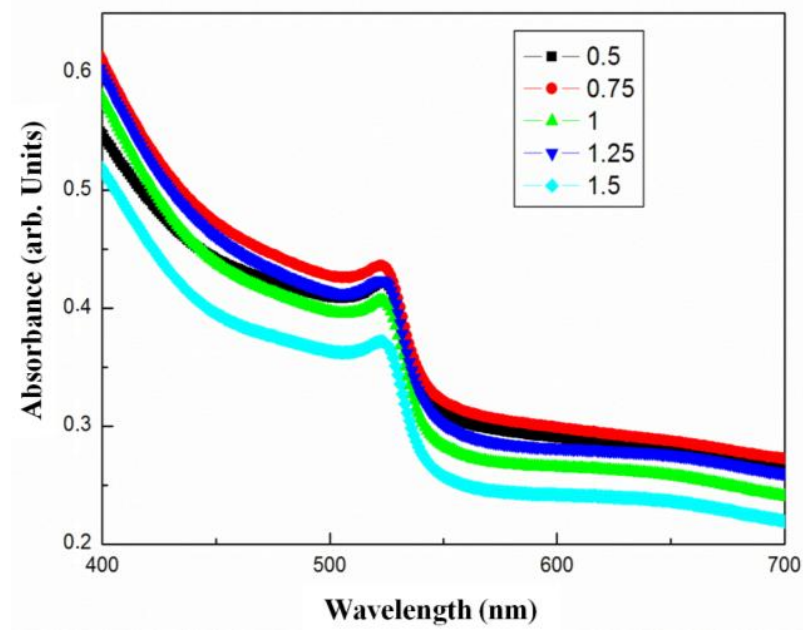

Fig.4

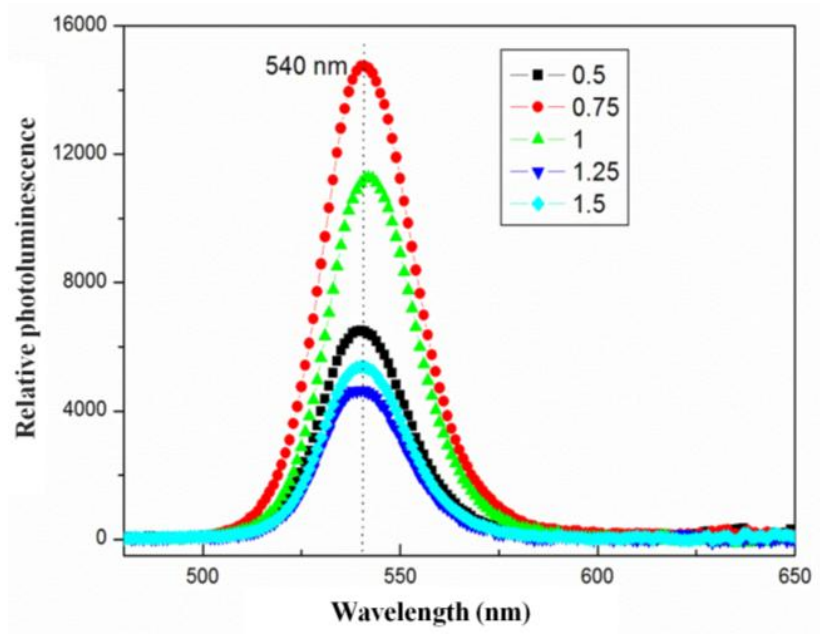

Fig.5

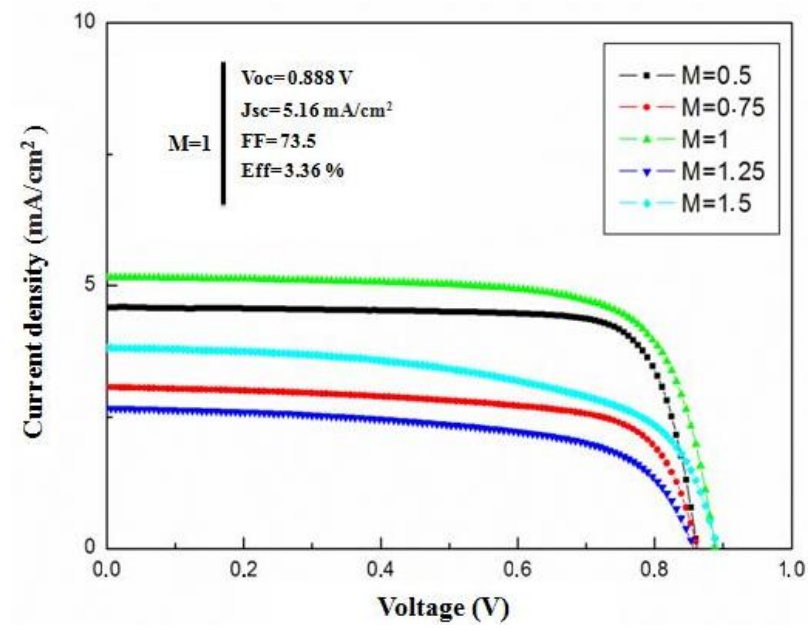

Fig.6 